RESIDENT

\& FELLOW

SECTION

Section Editor

Mitchell S.V. Elkind,

MD, MS

Yong-Qing Zhang, MD

Address correspondence and reprint requests to Dr. Yong-Qing Zhang, Xiafei Road 123, Xiamen, China yqzhmed@gmail.com
Supplemental data at www.neurology.org

\title{
Teaching Video NeuroImages: Regional myokymia
}

回星

Figure 1 Tibial nerve conduction studies showing consistent F-wave hyperexcitability

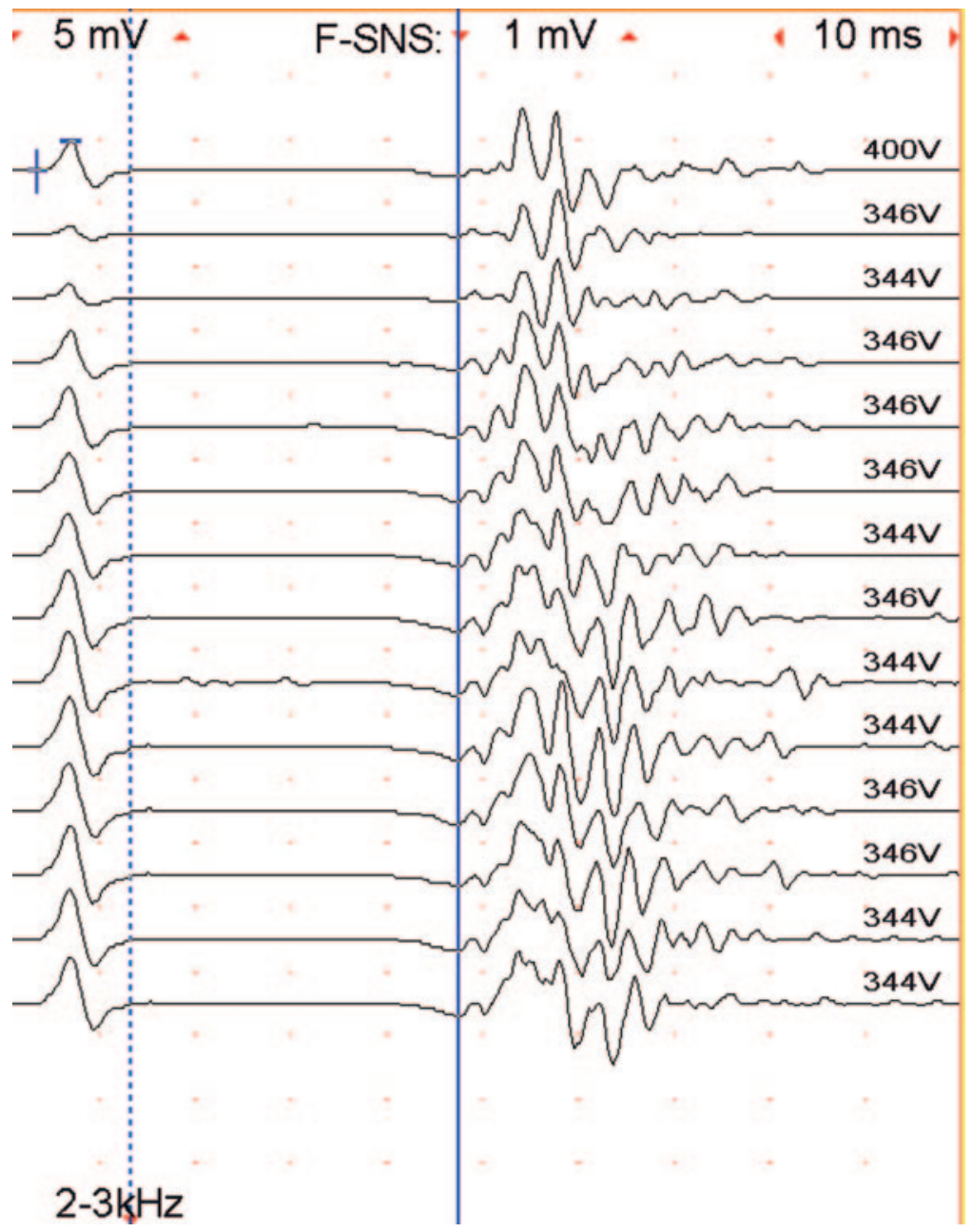

A 26-year-old man presented with involuntary muscle twitching of the bilateral lower extremities. The continuous muscle rippling was noted in bilateral calves, posterior thighs, and buttocks (video). Nerve conduction studies revealed F-wave hyperexcitability (figure 1). EMG recording showed doublet, triplet, and multiplet motor unit discharges (figure 2). The clinical presentation and electrophysiologic findings suggested a diagnosis of Isaac syndrome, although symptoms are typically regional rather than generalized. This patient was successfully treated with phenytoin. Isaac syndrome was first described in 1961, ${ }^{1}$ and is characterized by peripheral nerve hyperexcitability which manifests clinically as generalized muscle twitching, stiffness, pseudomyotonia, and cramping. Some patients have muscle hypertrophy and hyperhydrosis. Antibody to voltage-gated potassium channels can be detected in $40 \%$ of patients. 

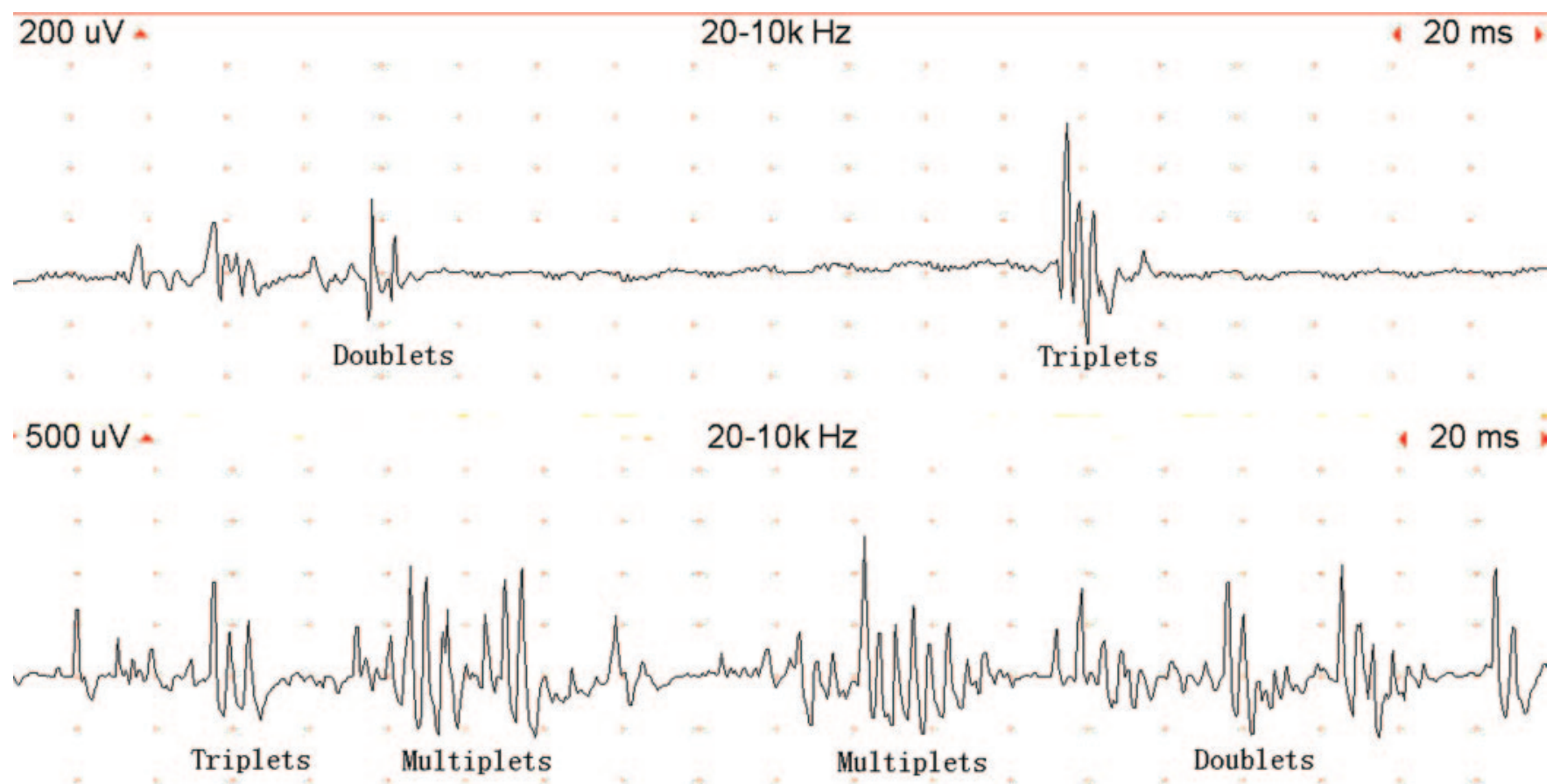

Associated autoimmune disorders and other autoantibodies are found in approximately $50 \%$, most notably antiacetylcholine receptor antibodies, indicating coexistent myasthenia gravis in about $20 \%$. Typical EMG findings include continuous single motor unit discharges occurring as doublets, triplets, and multiplet single unit discharges firing at a high intraburst frequency $(150-300 \mathrm{~Hz}$; neuromyotonic discharges), and at lower frequencies (less than 60
$\mathrm{Hz}$; myokymic discharges). The symptoms often respond well to anticonvulsants such as phenytoin and carbamazepine. ${ }^{2}$

\section{REFERENCES}

1. Isaacs $\mathrm{H}$. A syndrome of continuous muscle-fibre activity. J Neurol Neurosurg Psychiatry 1961;24:319-325.

2. Maddison P. Neuromyotonia. J Clin Neurophysiol 2006; 117:2118-2127. 


\title{
Neurology
}

\author{
Teaching Video NeuroImages: Regional myokymia \\ Yong-Qing Zhang \\ Neurology 2010;74; e103-e104 \\ DOI 10.1212/WNL.0b013e3181e2410f
}

This information is current as of June 7, 2010

\section{Updated Information \& \\ Services}

Supplementary Material

References

Subspecialty Collections

Permissions \& Licensing

Reprints including high resolution figures, can be found at: http://n.neurology.org/content/74/23/e103.full

Supplementary material can be found at: http://n.neurology.org/content/suppl/2010/06/06/74.23.e103.DC1

This article cites 2 articles, 1 of which you can access for free at: http://n.neurology.org/content/74/23/e103.full\#ref-list-1

This article, along with others on similar topics, appears in the following collection(s):

All Neuromuscular Disease

http://n.neurology.org/cgi/collection/all_neuromuscular_disease

Autoimmune diseases

http://n.neurology.org/cgi/collection/autoimmune_diseases

EMG

http://n.neurology.org/cgi/collection/emg

Information about reproducing this article in parts (figures,tables) or in its entirety can be found online at:

http://www.neurology.org/about/about_the_journal\#permissions

Information about ordering reprints can be found online: http://n.neurology.org/subscribers/advertise

Neurology ${ }^{\circledR}$ is the official journal of the American Academy of Neurology. Published continuously since 1951, it is now a weekly with 48 issues per year. Copyright . All rights reserved. Print ISSN: 0028-3878. Online ISSN: 1526-632X.

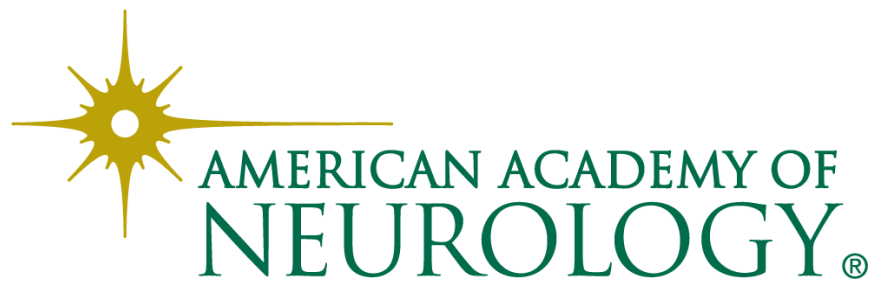

